\title{
Alternative splicing of $B C L-X$ and implications for treating hematological malignancies (Review)
}

\author{
WANLING CHEN ${ }^{1}$ and JINGGANG $\mathrm{LI}^{2}$ \\ ${ }^{1}$ Department of Clinical Medicine, Xiamen Medical College, Xiamen, Fujian 361023; ${ }^{2}$ Department of Hematology, \\ Fujian Institute of Hematology, Fujian Medical University Union Hospital, Fuzhou, Fujian 350001, P.R. China
}

Received February 17, 2021; Accepted May 19, 2021

DOI: $10.3892 / \mathrm{ol} .2021 .12931$

\begin{abstract}
B C L-X$ is a member of the BCL-2 family. It regulates apoptosis and plays a critical role in hematological malignancies. It is well-known that $>90 \%$ of human genes undergo alternative splicing. A total of 10 distinct splicing transcripts of the $B C L-X$ gene have been identified, including transcript variants 1-9 and ABALON. Different transcripts from the same gene have different functions. The present review discusses the progress in understanding the different alternative splicing transcripts of $B C L-X$, including their characteristics, functions and expression patterns. The potential use of $B C L-X$ in targeted therapies for hematological malignancies is also discussed.
\end{abstract}

\section{Contents}

1. Introduction

2. Alternative splicing of $B C L-X$

3. Function of $B C L-X$ splicing variants in hematopoietic cells

4. Expression and clinical significance of $B C L-X$ splicing variants

5. Therapies targeting $B C L-X$ for hematological malignancies

6. Conclusion

\section{Introduction}

$B C L-X$ is a member of the $B C L-2$ gene family (1). The proteins in this family share homology over four conserved regions referred to as the $\mathrm{BH} 1-4$ domains that determine dimer formation of the proteins, as well as their function in regulating apoptosis (1) Of the four domains, the $\mathrm{BH} 1, \mathrm{BH} 2$ and $\mathrm{BH} 3$ domains facilitate the formation of a hydrophobic slit, which

Correspondence to: Dr Wanling Chen, Department of Clinical Medicine, Xiamen Medical College, 1999 Guankouzhong Road, Jimei, Xiamen, Fujian 361023, P.R. China

E-mail: xmmcxinxin@126.com

Key words: $B C L-X$, alternative splicing, hematological malignancies is involved in the uptake of the $\mathrm{BH} 3$ domain of pro-apoptotic proteins via heterodimerization; the $\mathrm{BH} 4$ domain is often absent in pro-apoptotic proteins, but present in antiapoptotic activity $(2,3)$.

$B C L-X$ regulates apoptosis and plays a critical role in hematopoiesis, lymphopoiesis and hematological malignancies (4-6). Motoyama et al (6) performed experiments in which homologous recombination was applied to knockout $B C L-X$. The results demonstrated that $B C L-X$ plays a pivotal role in supporting immature lymphocytes survival. In addition, several studies have reported its key role in the lifespan of mature hematopoietic cells, including terminal differentiation stages of erythropoiesis and differentiated megakaryocytes (5,7). Mice deficient in $B C L-X$ are anemic and develop severe thrombocytopenia (8). Deregulated expression of $B C L-X$ function may also play a role in the pathogenesis of some hematologic disorders, particularly polycythemia vera (9).

Recently, it has been suggested that $>90 \%$ of human genes undergo alternative splicing (10). Different transcripts from the same gene have the same or different expression pattern and functions (11-14). Rosa et al (11) reported that six transcript variants of ZNF695 are co-expressed in cancer cell lines, and transcript variant one and three were predominantly expressed in leukemia. Handschuh et al (12) demonstrated that all three NPM1 transcripts are upregulated in leukemia compared with control samples. However, Zeilstra et al (13) reported that CD44 variant isoforms (CD44v), but not CD44s, have unique functions in promoting adenoma initiation in Apc $(\mathrm{Min} /+)$ mice. In addition, the $\mathrm{H} 2 \mathrm{AFY}$ gene encodes $\mathrm{H} 2 \mathrm{~A}$ histone variant MacroH2A1, including two isoforms (MacroH2A1.1 and MacroH2A1.2) (15). MacroH2A1.1 is predominantly expressed in differentiated cells, while MacroH2A1.2 is preferentially expressed over 1.1 in proliferative cells (14). The MacroH2A1.1 isoform presents as pleiotropic tumor suppressor, by repressing cellular processes, including cell proliferation, migration and invasion, whereas the function of MacroH2A1.2 is mainly cancer-type dependent (14).

A total of 10 distinct splicing transcripts of the $B C L-X$ gene have been identified, including transcript variants 1-9 and ABALON. The present review discusses the progress in understanding the alternative splicing transcripts of $B C L-X$ in terms of their characteristics, functions and expression patterns. The potential use of $B C L-X$ in targeted therapies for hematological malignancies is also discussed. 


\section{Alternative splicing of $B C L-X$}

$B C L-X$, also known as $B C L 2 L 1, B C L 2 L$ and PPP1R52, is located at $20 \mathrm{q} 11.21(16,17)$. The $B C L-X$ gene was first identified through a screen of the chicken lymphoid cDNA library with a probe for the $B C L-2$ gene at low stringency (1). The gene, such as other genes, including ZNF695, NPM1 and H2AFY, is associated with alternative splicing, and 10 transcripts have been identified to date (transcript variants 1-9 and ABALON; Fig. 1 and Table I).

Variant 1 (GenBank: NM_138578.3) represents the longest transcript, with 2,574 base pairs (bp) and contains an open reading frame (ORF, 702 bp) (Table I). It encodes a protein with 233 amino acids that displays $44 \%$ amino acid identity with human BCL-2 (1). Thus, this splicing variant encodes the longer isoform BCL- $\mathrm{X}_{\mathrm{L}}$ (B cell lymphoma-extra-large; Bcl211), also known as BCL-xL. Variants 3 (NM_001317919.2), 4 (NM_001317920.2), 5 (NM_001317921.2), 7 (NM_001322239.2), 8 (NM_001322240.2) and 9 (NM_001322242.2) differ from variant 1 in the 5'untranslated region, whereas their ORFs are the same as that of variant 1 . Therefore, they encode the same isoform as transcript variant 1 (Table I). The ORFs and amino acid sequence of BCL- $\mathrm{X}_{\mathrm{L}}$ are presented in Table II.

Transcript variant 2 (NM_001191.4) also derives from $B C L-X$, with a length of $2,385 \mathrm{bp}$. Its sequence is different from that of variant 1 in the second exon, which is the result of differential usage of two 5' splice sites within the first coding exon (Table II). This difference results in the absence of the sequence encoding the 63 amino acids of the BCL- $\mathrm{X}_{\mathrm{L}} \mathrm{ORF}$, which display the greatest homology to BCL-2 (1). This results in a shorter ORF with 513 bp compared with variant 1 , and thus, the variant encodes a 170 -amino acid protein named isoform BCL- $\mathrm{X}_{\mathrm{S}}$ (Table II).

Variant 6 (NR_134257.1) contains a different internal exon from variant 1 and is considered a non-coding RNA as use of the same 5'-most supported translational start codon found in variant 1 generates the potential for nonsense-mediated mRNA decay. Another long non-coding RNA generated by alternative splicing of the primary $B C L-X$ RNA transcript is INXS (also named ABALON, NR_131907.1), which is 1,903 bp in length (Table I).

$B C L-X$ can be alternatively spliced to produce 10 transcripts. Among them, seven transcripts encode the same isoform $\mathrm{BCL}-\mathrm{X}_{\mathrm{L}}$, whereas the transcript variant 2 translates the shorter isoform BCL- $\mathrm{X}_{\mathrm{S}}$. Besides, two long non-coding RNAs are also generated from the gene. Currently, there are no reports on the two non-coding RNAs (variant 6 and INXS) derived from $B C L-X$. Thus, the present review focuses on these two splice isoforms (BCL- $\mathrm{X}_{\mathrm{L}}$ and BCL- $\mathrm{X}_{\mathrm{S}}$ ).

\section{Function of $B C L-X$ splicing variants in hematopoietic cells}

$B C L-X_{L}$ that inhibit apoptosis or promote compensatory proliferation. It is well-known that variants of $B C L-X$ regulate apoptosis (2). While BCL- $\mathrm{X}_{\mathrm{L}}$ inhibits apoptosis, BCL-Xs has pro-apoptotic functions via the inhibition of BCL-2 and BCL- $X_{L}(1)$. BCL- $X_{L}$ protein binds and sequesters pro-apoptotic $\mathrm{Bak} / \mathrm{Bax}$ proteins via their $\mathrm{BH} 3$ domains, which inactivates them (18) and prevents caspase activation (19-21). This renders the cells resistant to apoptotic cell death $(1,18-21)$. However, it has been reported that $\mathrm{BCL}-\mathrm{X}_{\mathrm{L}}$ and $\mathrm{Bax}$ also act independently to support cell survival, based on findings that BCL- $\mathrm{X}_{\mathrm{L}}$ can limit apoptosis independent of Bax expression, and that BCL- $X_{L}$ protects B cells from immunosuppressant-induced apoptosis (22). Furthermore, while BCL- $\mathrm{X}_{\mathrm{L}}$ cannot stop cell damage and cell cycle arrest induced by certain drugs, it can contribute to lower rates of cell death following drug treatment (23-25).

Josefsson et al (26) demonstrated that deletion of BCL- $\mathrm{X}_{\mathrm{L}}$ leads to megakaryocyte apoptosis and failure of platelet shedding. Conversely, Kaluzhny et al (27) reported that overexpression of BCL- $\mathrm{X}_{\mathrm{L}}$ in megakaryocytes (MKs) increases the number of MKs and decreases apoptosis. In addition, $B C L-X_{L}$ expression is necessary for the survival of reticulocytes and MKs, and the absence of functional BCL- $\mathrm{X}_{\mathrm{L}}$ expression results in anemia and thrombocytopenia $(8,28-31)$. Dolznig et al (32) interpreted the mechanism of anemia due to loss of BCL- $\mathrm{X}_{\mathrm{L}}$. The authors demonstrated that during erythroid maturation, erythropoietin (Epo) regulates the number of red blood cells via apoptosis inhibition arising from Epo-dependent upregulation of BCL- $\mathrm{X}_{\mathrm{L}}$ (32). Furthermore, overexpression of erythroid progenitors BCL- $\mathrm{X}_{\mathrm{L}}$ also can induce erythroid colonies without Epo (33).

Harb et al (34) reported that BCL- $\mathrm{X}_{\mathrm{L}}$ does not inhibit leukemogenesis or affect the apoptosis of tumor cells. The authors clarified the role of BCL- $\mathrm{X}_{\mathrm{L}}$ in Philadelphia chromosome-positive $(\mathrm{Ph}+) \mathrm{B}$-cell acute lymphoblastic leukemia using two mouse models, and the results demonstrated that loss of BCL- $\mathrm{X}_{\mathrm{L}}$ expression does not prohibit leukemogenesis or alter the percentage of apoptotic cells, but promotes cellular proliferation. Conversely, overexpression of BCL- $\mathrm{X}_{\mathrm{L}}$ decreases cellular proliferation. These results identified unexpected functions of BCL- $\mathrm{X}_{\mathrm{L}}$ in cell-cycle entry and tumor cell proliferation. Studies in mice lacking $B C L-X$ expression have suggested that $\mathrm{BCL}-\mathrm{X}_{\mathrm{L}}$ expression may be essential to the survival of proliferating hematopoietic precursor cells $(6,34)$.

$B C L-X_{S}$ that promote apoptosis and are associated with $B C L-X_{L}$. BCL- $X_{S}$ expression can block resistance to apoptosis induced by overexpression of BCL-2 (1,35). Accordingly, $\mathrm{BCL}-\mathrm{X}_{\mathrm{S}}$ expression has been demonstrated to promote apoptosis by inhibiting the anti-apoptotic function of BCL-2 (1). Additional research demonstrating heterodimer formation between $\mathrm{BCL}-\mathrm{X}_{\mathrm{S}}$ and $\mathrm{BCL}-\mathrm{X}_{\mathrm{L}}$, as well as heteromultimer formation of these proteins with BCL-2, suggested that $B C L-X_{S}$ play a dominant role in inactivating BCL-2 or BCL- $_{\mathrm{L}}(35)$.

Consistently, BCL- $\mathrm{X}_{\mathrm{S}}$ was recently demonstrated to limit the protective effects of $\mathrm{BCL}-\mathrm{X}_{\mathrm{L}}$ in the contexts of growth factor withdrawal and chemotherapeutic drug treatment (36). Thus, relative expression of BCL- $\mathrm{X}_{\mathrm{S}}$ and BCL- $\mathrm{X}_{\mathrm{L}}$ may be essential in balancing cell death and survival during hematopoietic cell differentiation.

\section{Expression and clinical significance of $B C L-X$ splicing variants}

$B C L-X$ is differentially expressed in different differentiated hematopoietic cells and lymphoid tissues. In 1993, BCL-X 


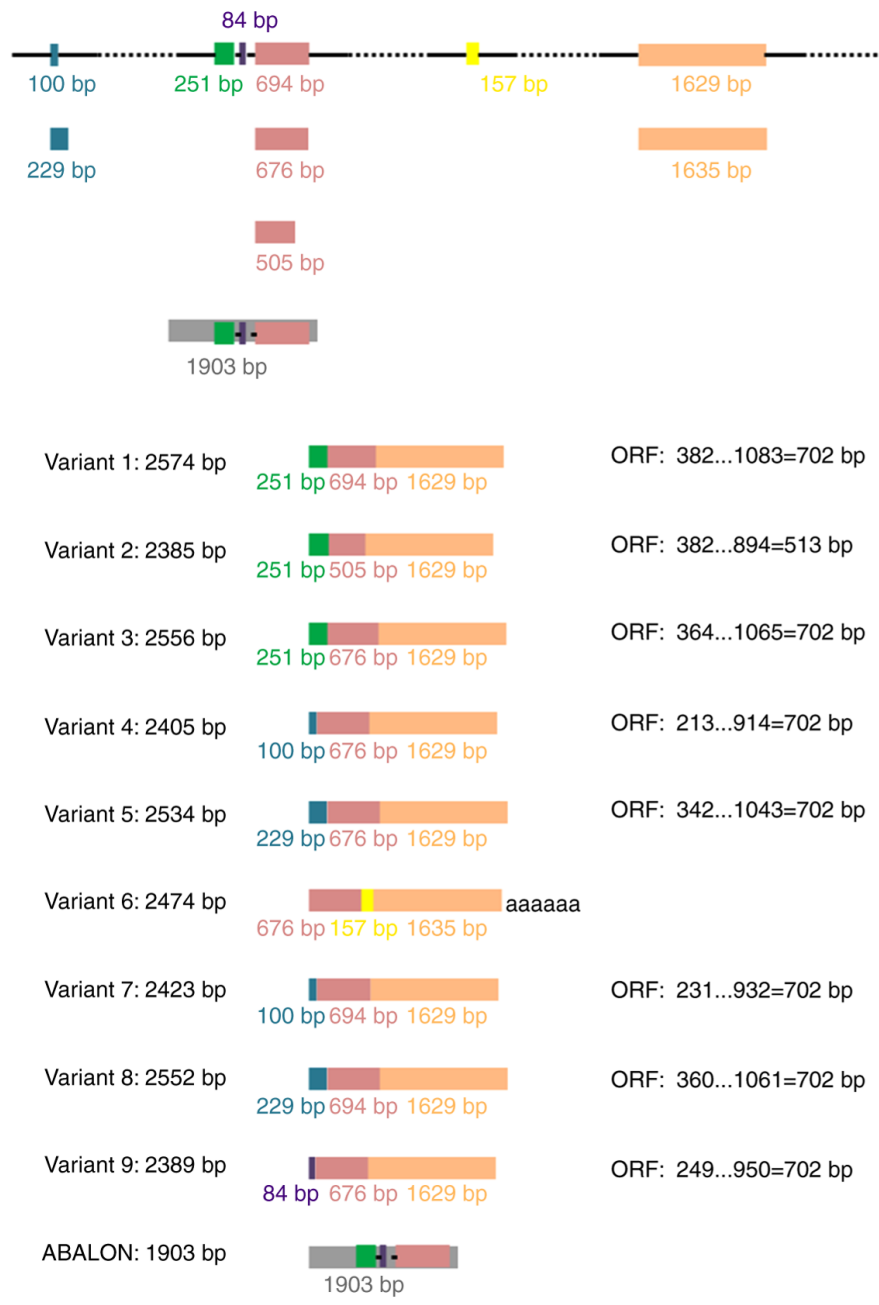

Figure 1. Alternative splicing transcripts of $B C L-X . B C L-X$ consists of 11 exons on the same DNA strand. The size and location of each exon in the genome are depicted on the right-hand side. Colored boxes represent exons. Blue boxes represent variable exons with 100 and 229 bp. Green box represents exon with a length of $251 \mathrm{bp}$. Purple boxes represent exons which are 84 bp in length. Red boxes represent variable exons with 694, 676 and 505 bp. Yellow boxes represent exons with a length of $157 \mathrm{bp}$. Orange boxes represent variable exons with 1,629 and 1,635 bp. In addition, the grey exon with $1903 \mathrm{bp}$ covers a region of exons painted green, purple and red. A total of 10 distinct splicing transcripts were produced through alternative splicing, including eight mRNAs encoding two protein isoforms and two non-coding RNAs. ORF, open reading frame; bp, base pair.

mRNA expression was observed in a variety of tissues (thymus, bursa and the central nervous system), with the highest levels observed in lymphoid and the central nervous system (1). Although $B C L-X$ mRNA expression is not observed in single-positive thymocytes or mature peripheral blood $\mathrm{T}$ cells, rapid induction of high levels of $B C L-X$ mRNA expression has been observed following mitogenic activation (1). In addition, double-positive thymocytes express higher levels of BCL-X $\mathrm{S}_{\mathrm{S}}$ compared with BCL-X $\mathrm{X}_{\mathrm{L}}(1)$. However, Ohta et al (37) reported that the $\mathrm{BCL}-\mathrm{X}_{\mathrm{L}}$ protein, but not the $\mathrm{BCL}-\mathrm{X}_{\mathrm{S}}$ protein, is expressed in hematolymphoid tissue.

In 1994, Krajewski et al (38) reported the detection of $B C L-X$ immunostaining in precursors of myeloid cells and metamyelocytes. The authors demonstrated that most bone marrow polymorphonuclear cells lack $B C L-X$ expression along with most spleen and peripheral blood granulocytes, in accordance with other studies $(37,39,40)$. Subsequently, Sanz et al (40) demonstrated that peripheral blood monocytes and alveolar macrophages are positive for $B C L-X$. In addition, $B C L-X$ expression levels are either maintained or upregulated during monocyte/macrophage differentiation but downregulated with the maturation of myeloid progenitors into polymorphonuclear cells $(40,41)$. Furthermore, $B C L-X$ expression during erythropoiesis is notably increased in terminally differentiated erythroblasts (42).

Sanz et al (40) demonstrated that BCL- $\mathrm{X}_{\mathrm{L}}$ is the most highly expressed form of $B C L-X$ in HL-60 and CD34+ cells differentiating into monocytes/macrophages. Furthermore, $B C L-X_{\mathrm{L}}$ is the predominant $B C L-X$ form expressed in peripheral blood mononuclear cells (43). However, in hematopoietic precursors, the predominant $B C L-X$ form is BCL- $\mathrm{X}_{\mathrm{S}}(44)$. Andreeff et al (45) reported that in normal hematopoietic progenitor cells, BCL- $X_{\mathrm{L}}$ is highly expressed in the earliest CD34 $4^{+} / 33^{-} / 13^{-}$compartment and to a lesser extent in $\mathrm{CD} 34^{+} / 13^{+}$cells, but is absent in promyelocytes (CD34-/33+). Furthermore, BCL- $\mathrm{X}_{\mathrm{S}}$ was detectable only in the most immature CD34 $/ 33^{-} / 13^{-}$compartment (45). In addition, $\mathrm{BCL}-\mathrm{X}_{\mathrm{L}}$ and $\mathrm{BCL}-\mathrm{X}_{\mathrm{S}}$ are not expressed in neutrophils (43), and the expression of BCL- $\mathrm{X}_{\mathrm{S}}$ has not been detected in erythroid cells (42).

Different expression patterns of $B C L-X_{L}$ and $B C L-X_{S}$ in hematological malignancies. BCL- $X_{\mathrm{L}}$ has been detected in a variety 


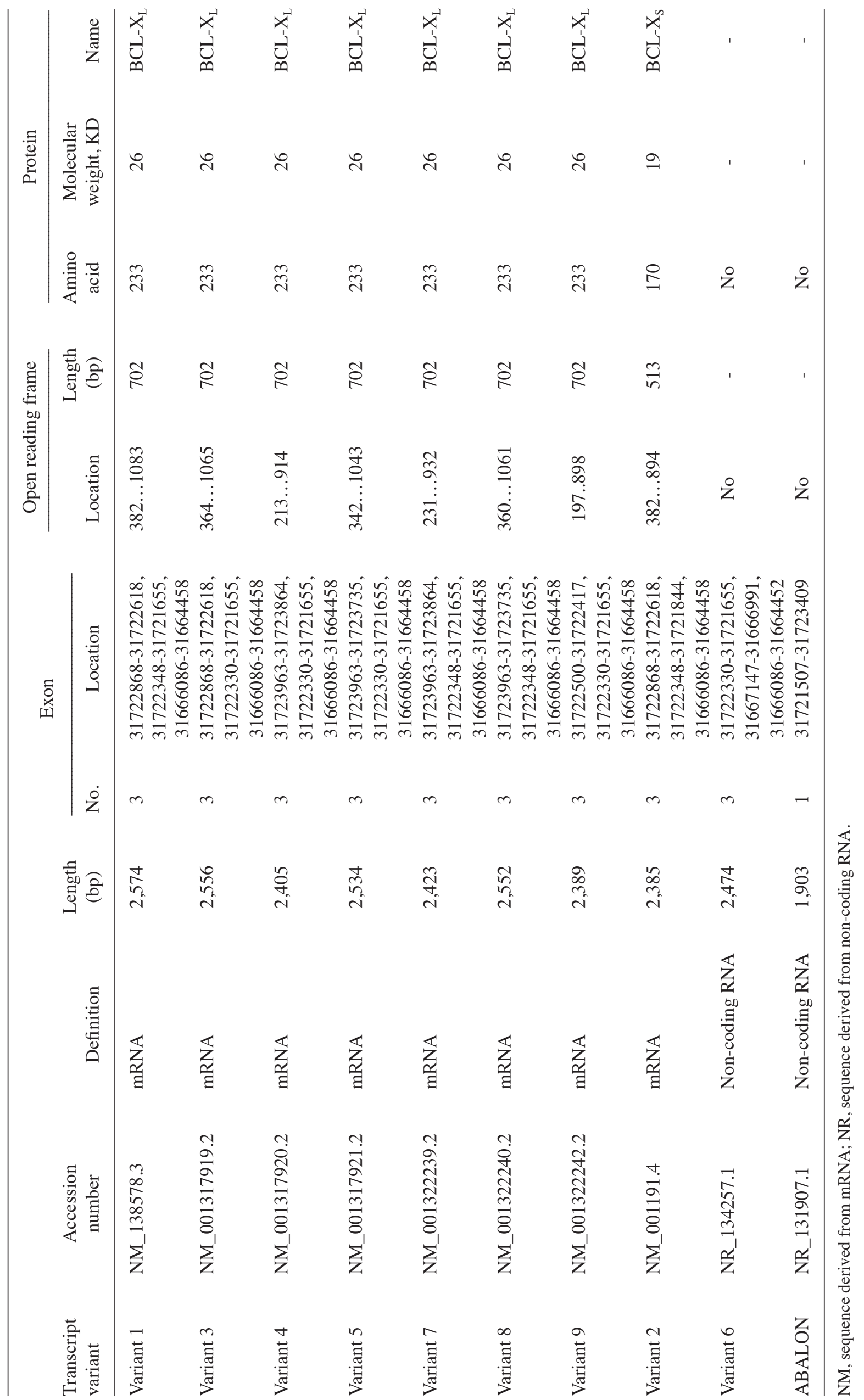


Table II. ORF and encoding amino acid sequence of $B C L-X$.

Sequence

\begin{tabular}{|c|c|}
\hline \multirow[t]{20}{*}{ ORF (702 nt) } & $\begin{array}{l}\text { ATGTCTCAGAGCAACCGGGAGCTGGTGGTTGACTTTCTCTCCTACAAGCTTTCCCAGAAAG } \\
\text { GATACAGCT }\end{array}$ \\
\hline & GATACAGCT \\
\hline & GGAGTCAGTTTAGTGATGTGGAAGAGAACAGGACTGAGGCCCCAGAAGGGACTGAATCGG \\
\hline & AGATGGAGAC \\
\hline & CCCCAGTGCCATCAATGGCAACCCATCCTGGCACCTGGCAGACAGCCCCGCGGTGAATGGA \\
\hline & GCCACTGGC \\
\hline & CACAGCAGCAGTTTGGATGCCCGGGAGGTGATCCCCATGGCAGCAGTAAAGCAAGCGCTGA \\
\hline & GGGAGGCAG \\
\hline & GCGACGAGTTTGAACTGCGGTACCGGCGGGCATTCAGTGACCTGACATCCCAGCTCCACATC \\
\hline & ACCCCAGG \\
\hline & GACAGCATATCAGAGCTTTGAACAGGTAGTGAATGAACTCTTCCGGGATGGGGTAAACTGGG \\
\hline & GTCGCATT \\
\hline & GTGGCCTTTTTCTCCTTCGGCGGGGCACTGTGCGTGGAAAGCGTAGACAAGGAGATGCAGGT \\
\hline & ATTGGTGA \\
\hline & GTCGGATCGCAGCTTGGATGGCCACTTACCTGAATGACCACCTAGAGCCTTGGATCCAGGAGA \\
\hline & ACGGCGG \\
\hline & CTGGGATACTTTTGTGGAACTCTATGGGAACAATGCAGCAGCCGAGAGCCGAAAGGGCCAGG \\
\hline & $\underline{\text { AACGCTTC }}$ \\
\hline & AACCGCTGGTTCCTGACGGGCATGACTGTGGCCGGCGTGGTTCTGCTGGGCTCACTCTTCAGT \\
\hline & CGGAAATGA \\
\hline \multirow[t]{7}{*}{ Protein $(233$ aa) } & MSQSNRELVVDFLSYKLSQKGYSWSQFSDVEENRTEAPEGTESEMETPSAINGNPSWHLADSPAV \\
\hline & NGATG \\
\hline & HSSSLDAREVIPMAAVKQALREAGDEFELRYRRAFSDLTSQLHITPGTAYQSFEQVVNELFRDGV \\
\hline & NWGRI \\
\hline & VAFFSFGGALCVESVDKEMQVLVSRIAAWMATYLNDHLEPWIQENGGWDTFVELYGNNAAAES \\
\hline & RKGQERF \\
\hline & GVVLLGSLFSRK \\
\hline
\end{tabular}

ORF, open reading frame; NT, nucleotide; AA, amino acid. The second coding exon of ORF are underlined. The absence of the sequence encoding the 63 amino acids of BCL-XL are indicated in bold.

of hemopoietic cell types, including lymphoid and myeloid leukemia lines, such as HL-60, K562, KG1a, ML-1, Molt3, Jurkat, Raji and CEM $(46,47)$. However, BCL-X S $_{\text {is weakly }}$ expressed in K562 and VAL lines (lymphoid lines) (48) and not expressed in AS-E2 cells (49).

Upregulated BCL- $\mathrm{X}_{\mathrm{L}}$ expression was observed in both acute myeloid leukemia (AML) (46) and acute lymphocytic leukemia (ALL) (50). Bogenberger et al (51) measured BCL- $\mathrm{X}_{\mathrm{L}}$ expression in 577 patients with primary AML using a reverse phase protein array proteomic approach. The results demonstrated that normal CD34+ progenitor cells express less BCL- $\mathrm{X}_{\mathrm{L}}$ than most FAB classifications, and BCL- $\mathrm{X}_{\mathrm{L}}$ expression is higher in M6 compared with other AML FAB classifications (51). BCL-X $\mathrm{L}_{\mathrm{L}}$ is highly expressed in leukemic $\mathrm{CD}^{+} 4^{+} / 13^{+}$ or CD34-/13+ cells $(44,45)$. Notably, the percentages of BCL-Xs positive cells among M2 and M3 types were higher than those in other types (48). Furthermore, significantly lower expression of BCL-X $\mathrm{X}_{\mathrm{S}}$ was observed in CD34+ vs. CD34-leukemias (48).

In addition to acute leukemia, BCL- $\mathrm{X}_{\mathrm{L}}$ and $\mathrm{BCL}-\mathrm{X}_{\mathrm{S}}$ have been detected in other hemopoietic diseases. For example, Gottardi et al (52) observed high BCL-X $\mathrm{L}_{\mathrm{L}}$ levels during the leukemic phase in 16 of $23 \mathrm{~B}$ cell type chronic lymphocytic leukemia (B-CLL) cases and 8/11 mantle cell lymphoma (MCL) cases (52), while BCL-X $\mathrm{X}_{\mathrm{S}}$ was observed in only low-to-trace amounts during the leukemic phase in 13/23 B-CLL cases and 6/11 of MCL cases (52). In addition, Brousset et al (53) recently reported on the frequent expression of $B C L-X$ in Reed-Sternberg cells of 1 Hodgkin's disease. Zhang et al (41) evaluated BCL- $\mathrm{X}_{\mathrm{L}}$ expression during differentiation of megakaryocytic cells from essential thrombocythemia (ET) patients. The authors demonstrated that BCL- $\mathrm{X}_{\mathrm{L}}$ protein expression is downregulated in ET during differentiation of megakaryocytes.

Clinical significance in hematological malignancies. Expression of apoptosis-regulating protein $B C L-X$ in AML blasts at diagnosis is associated with disease-free survival (54). Recent studies have reported that overexpression of $\mathrm{BCL}-\mathrm{X}_{\mathrm{L}}$ leads to cellular resistance to various pharmaceutical agents, such as etoposide, doxorubicin, cisplatin, vincristine, bleomycin and paclitaxel, as well as ionizing radiation $(23,50,55-59)$. Overexpression of $\mathrm{BCL}-\mathrm{X}_{\mathrm{L}}$ has also 
been associated with poor clinical outcomes in patients with AML (58). However, research indicates no gain in prognostic information from BCL-X $\mathrm{L}_{\mathrm{L}}$ expression (60). Reverse transcription PCR analysis demonstrated high levels of BCL- $\mathrm{X}_{\mathrm{L}}$ mRNA in minimal residual disease (MRD) but not in normal cells (45).

Campos et al (48) revealed an inverse correlation between the percentages of BCL-2- and BCL- $\mathrm{X}_{\mathrm{S}}$-positive cells in AML and ALL. Among the 57 patients included in the study, 37 experienced complete remission (CR), and samples from these patients contained a significantly higher percentage of BCL- $\mathrm{X}_{\mathrm{S}}$-expressing cells compared with samples from patients who did not achieve CR (48). Notably, BCL-X S $_{\mathrm{S}}$ expression was observed with greater frequency in T-cell leukemias than in B-cell leukemias and was associated with a higher remission rate. Notably, for both AML and ALL, the remission rates were higher among patients with leukemic cells expressing $\mathrm{BCL}_{\mathrm{S}}(\mathrm{X})$. Cell lines hyperexpressing $\mathrm{BCL}-\mathrm{X}_{\mathrm{S}}$ are also more sensitive to viral- or chemotherapy-induced apoptosis $(61,62)$.

Deng et al (63) observed a higher ratio of $\mathrm{BCL}-\mathrm{X}_{\mathrm{L}}$ to BCL-X $\mathrm{X}_{\mathrm{S}}$ expression in patients with $\mathrm{AML}$, with a poor prognosis $(-5,-7)$ than those with a good prognosis [inv16, $t(8 ; 21)]$. The authors reported a higher ratio of $\mathrm{BCL}-\mathrm{X}_{\mathrm{L}}$ to $\mathrm{BCL}-\mathrm{X}_{\mathrm{S}}$ expression in chemoresistant subtypes compared with chemosensitive subtypes (63). An increase in the ratio of BCL-X to $\mathrm{BCL}-\mathrm{X}_{\mathrm{S}}$ expression was also observed in MRD of AML compared with de novo diagnosed AML (45).

\section{Therapies targeting $B C L-X$ for hematological malignancies}

The BH3 mimetics, such as ABT-199 (venetoclax), ABT-737 and ABT-263 (navitoclax), are small molecules that mimic the BH3 domains of BCL-2 family proapoptotic proteins $(60,62)$. They have been used to bind and antagonize the functions of BCL-2 and/or BCL-X $\mathrm{L}_{\mathrm{L}}$ to promote cell death in hematological malignancies (64-69).

ABT-199 specifically targets BCL-2 protein and has low

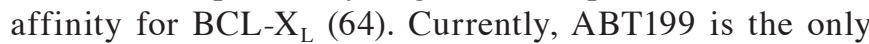
US food and drug administration-approved antitumor agent targeting the BCL-2 family of proteins, and is useful for the treatment of certain hematologic malignancies, such as AML and CLL (70-72). However, prolonged monotherapy tends to beget resistance to ABT-199, and the report indicated that targeting of myeloid cell leukemia-1 (MCL-1) and BCL-X can restore sensitivity to the ABT-199 among previously resistant AML cell lines, which would delay or even prevent the development of drug resistance in these cells (73). In addition, co-expression of high BCL-2 levels with low BCL- $\mathrm{X}_{\mathrm{L}}$ levels was demonstrated to render multiple myeloma (MM) cell lines sensitive to ABT-199, whereas co-expression of BCL-2 and $\mathrm{BCL}-\mathrm{X}_{\mathrm{L}}$ was associated with resistance to ABT-199, but sensitivity to the BCL- $\mathrm{X}_{\mathrm{L}}$-selective inhibitor A-1155463 in MM cells (73,74).

The ABT-737 molecule has a high affinity for BCL-2, BCL-X $\mathrm{X}_{\mathrm{L}}$ and BCL-W, but because it is not orally bioavailable, its administration via chronic single-agent therapy or in combination regimens is difficult (65). The orally bioavailable equivalent of ABT-737 is ABT-263 (66). ABT-263 treatment of tumor cells quickly leads to apoptosis by blocking interactions between $\mathrm{Bcl}-2 / \mathrm{Bcl}-\mathrm{X}_{\mathrm{L}}$ and pro-death proteins, as well as by inducing Bax translocation and cytochrome c release (66). In a xenograft model of ALL, oral ABT-263 treatment alone induced complete tumor regression, and even though ABT-263 exhibited limited efficacy as a single-agent treatment in xenograft models of aggressive B-cell lymphoma and MM, it significantly enhanced the efficacies of other commonly used therapeutic regimens (63). These findings provided the necessary evidence for clinical trials of the effectiveness of ABT-263 for treating B-cell malignancies (66). Despite the promising efficacy of ABT-263 observed in preclinical studies $(65,66)$, thrombocytopenia resulting from the inhibition of $\mathrm{BCL}-\mathrm{X}_{\mathrm{L}}$ (a critical pro-survival factor in megakaryocytes/platelets) $(75,76)$ is a dose-limiting toxicity for the clinical use of ABT-263 (77).

To reduce the dose-limiting platelet toxicity of ABT263, Khan et al (78) converted it to DT2216, a BCL-X proteolysis-targeting chimera (PROTAC), that targets $\mathrm{BCL}_{-} \mathrm{X}_{\mathrm{L}}$ to the Von Hippel-Lindau E3 ligase, which is minimally expressed in platelets. PZ15227 is another BCL-X $\mathrm{L}_{\mathrm{L}}$ PROTAC, which targets BCL-X $\mathrm{L}_{\mathrm{L}}$ to the cereblon E3 ligase (79). BCL- $\mathrm{X}_{\mathrm{L}}$ PROTACs are bivalent small molecules containing a ligand that recognizes the target protein and recruit it to the E3 ligase. Target protein is polyubiquitinated and degraded in proteasome. These results confirm that BCL-X $\mathrm{L}_{\mathrm{L}}$ PROTACs have improved antitumor potency and reduced platelet toxicity compared with ABT263 (78,79).

The first selective BCL-X $\mathrm{L}_{\mathrm{L}}$ inhibitor, WEHI-539, was discovered via high-throughput screening and demonstrated to induce BAK-dependent apoptosis (68). Later research using fragment-based approaches led to the development of the $\mathrm{BCL}-\mathrm{X}_{\mathrm{L}}$ antagonists $\mathrm{A} 1155463$ and the next-generation drug A1331852 (80). Wang et al (81) proposed that A1155463 may effectively kill ABT-199-resistant AML cells via their high expression of BCL-X $\mathrm{L}_{\mathrm{L}}$. Although preclinical studies of A1155463 and A1331852 have produced promising results, these compounds have not yet entered clinical trials $(80-84)$.

The novel BH3 domain mimetic, JY-1-106, antagonizes BCL- $\mathrm{X}_{\mathrm{L}}$ and MCL-1, and has been reported to promote cell death among HL-60 cells when administered as a single-agent treatment and in combination with retinoids (85). In addition, the greatest reduction in cell viability was observed when JY-1-106 was applied in combination with the RAR $\gamma$ antagonist, SR11253 (72). These findings suggest that combined administration of a dual BCL-X $\mathrm{L}_{\mathrm{L}}$ MCL-1 inhibitor with retinoids may be a promising strategy for treating leukemia (85).

\section{Conclusion}

In conclusion, 10 distinct transcripts are generated from the $B C L-X$ gene. It encodes proteins, including $B C L-\mathrm{X}_{\mathrm{L}}$ and $\mathrm{BCL}_{\mathrm{S}}$, as well as non-coding RNAs, including variant 6 and INXS. The expression patterns and functions of variant 6 and INXS remain unknown; however, studies have provided valuable insights into the expression patterns and functions of $\mathrm{BCL}-\mathrm{X}_{\mathrm{L}}$ and $\mathrm{BCL}-\mathrm{X}_{\mathrm{S}}$ in hematological malignancies. Therapies based on targeting $B C L-X$ have been evaluated for their potential effectiveness against hematological malignancies, but a therapy with satisfactory 
clinical efficacy is yet to be discovered. Thus, continued efforts to develop better targeted therapies based on $B C L-X$ are required.

\section{Acknowledgements}

Not applicable.

\section{Funding}

The present review was sponsored by Fujian Provincial Health Technology Project of China (grant no. 2019-2-45), the Middle-aged and Young Teachers Foundation of Fujian Educational Committee in China (grant no. JAT190835), the National Undergraduate Innovation and Entrepreneurship Training Program of China (grant no. 201912631003) and the Fujian Provincial Undergraduate Innovation and Entrepreneurship Training Program of China (grant no. 202012631031)

\section{Availability of data and materials}

Not applicable.

\section{Authors' contributions}

WC conceived the present study. WC prepared the original draft and the figure. JL performed the literature analysis. WC revised the manuscript . Data authentication is not applicable. All authors read and approved the final manuscript.

\section{Ethics approval and consent to participate}

Not applicable.

\section{Patient consent for publication}

Not applicable.

\section{Competing interests}

The authors declare that they have no competing interests.

\section{References}

1. Boise LH, González-García M, Postema CE, Ding L, Lindsten T, Turka LA, Mao X, Nuñez G and Thompson CB: Bcl-x, a bcl-2-related gene that functions as a dominant regulator of apoptotic cell death. Cell 74: 597-608, 1993.

2. Opferman JT: Attacking cancer's Achilles heel: Antagonism of anti-apoptotic BCL-2 family members. FEBS J 283: 2661-275, 2016.

3. Delbridge AR and Strasser A: The BCL-2 protein family, BH3-mimetics and cancer therapy. Cell Death Differ 22: 1071-1080, 2015

4. Yang E and Korsmeyer SJ: Molecular thanatopsis: A discourse on the BCL2 family and cell death. Blood 88: 386-401, 1996.

5. Motoyama N, Kimura T, Takahashi T, Watanabe T and Nakano T: Bcl-x prevents apoptotic cell death of both primitive and definitive erythrocytes at the end of maturation. J Exp Med 189: 1691-1698, 1999.

6. Motoyama N, Wang F, Roth KA, Sawa H, Nakayama K, Nakayama K, Negishi I, Senju S, Zhang Q, Fujii S, et al: Massive cell death of immature hematopoietic cells and neurons in Bcl-x-deficient mice. Science 267: 1506-1510, 1995.
7. Shearn AI, Deswaerte V, Gautier EL, Saint-Charles F, Pirault J, Bouchareychas L, Rucker EB III, Beliard S, Chapman J, Jessup W, et al: Bcl-x inactivation in macrophages accelerates progression of advanced atherosclerotic lesions in Apoe(-/-) mice. Arterioscler Thromb Vasc Biol 32: 1142-1149, 2012.

8. Wagner KU, Claudio E, Rucker EB, Riedlinger G, Broussard C, Schwartzberg PL, Siebenlist U and Hennighausen L: Conditional deletion of the Bcl-x gene from erythroid cells results in hemolytic anemia and profound splenomegaly. Development 127: 4949-4958, 2000.

9. Silva M, Richard C, Benito A, Sanz C, Olalla I and Fernández-Luna JL: Expression of Bcl-x in erythroid precursors from patients with polycythemia vera. N Engl J Med 338: 564-571, 1998.

10. Johnson JM, Castle J, Garrett-Engele P, Kan Z, Loerch PM, Armour CD, Santos R, Schadt EE, Stoughton R and Shoemaker DD: Genome-wide survey of human alternative pre-mRNA splicing with exon junction microarrays. Science 302: 2141-2144, 2003.

11. Rosa R, Villegas-Ruíz V, Caballero-Palacios MC, Pérez-López EI, Murata C, Zapata-Tarres M, Cárdenas-Cardos R, Paredes-Aguilera R, Rivera-Luna R and Juárez-Méndez S: Expression of ZNF695 transcript variants in childhood B-cell acute lymphoblastic leukemia. Genes (Basel) 10: 716, 2019.

12. Handschuh L, Wojciechowski P, Kazmierczak M, Marcinkowska-Swojak M, Luczak M, Lewandowski K, Komarnicki M, Blazewicz J, Figlerowicz M and Kozlowski P: NPM1 alternative transcripts are upregulated in acute myeloid and lymphoblastic leukemia and their expression level affects patient outcome. J Transl Med 16: 232, 2018.

13. Zeilstra J, Joosten SP, van Andel H, Tolg C, Berns A, Snoek M, van de Wetering $M$, Spaargaren M, Clevers $H$ and Pals ST: Stem cell CD44v isoforms promote intestinal cancer formation in Apc(min) mice downstream of Wnt signaling. Oncogene 33: 665-670, 2014

14. Corujo D and Buschbeck M: Post-translational modifications of $\mathrm{H} 2 \mathrm{~A}$ histone variants and their role in cancer. Cancers (Basel) 10: 59, 2018.

15. Lee Y, Hong M, Kim JW, Hong YM, Choe YK, Chang SY, Lee KS and Choe IS: Isolation of cDNA clones encoding human histone macroH2A1 subtypes. Biochim Biophys Acta 1399: 73-77, 1998.

16. Harder JM, Ding Q, Fernandes KA, Cherry JD, Gan L and Libby RT: BCL2L1 (BCL-X) promotes survival of adult and developing retinal ganglion cells. Mol Cell Neurosci 51: 53-59, 2012.

17. International Stem Cell Initiative; Amps K, Andrews PW, Anyfantis G, Armstrong L, Avery S, Baharvand H, Baker J, Baker D, Munoz MB, et al: Screening ethnically diverse human embryonic stem cells identifies a chromosome 20 minimal amplicon conferring growth advantage. Nat Biotechnol 29: 1132-1144, 2011.

18. Willis SN, Chen L, Dewson G, Wei A, Naik E, Fletcher JI, Adams JM and Huang DC: Proapoptotic Bak is sequestered by Mcl-1 and Bcl-xL, but not Bcl-2, until displaced by BH3-only proteins. Genes Dev 19: 1294-1305, 2005.

19. Kluck RM, Bossy-Wetzel E, Green DR and Newmeyer DD: The release of cytochrome c from mitochondria: A primary site for Bcl-2 regulation of apoptosis. Science 275: 1132-1136, 1997.

20. Kim CN, Wang X, Huang Y, Ibrado AM, Liu L, Fang G and Bhalla K: Overexpression of $\mathrm{Bcl}-\mathrm{X}(\mathrm{L})$ inhibits Ara-C-induced mitochondrial loss of cytochrome $\mathrm{c}$ and other perturbations that activate the molecular cascade of apoptosis. Cancer Res 57: 3115-3120, 1997.

21. Yang J, Liu X, Bhalla K, Kim CN, Ibrado AM, Cai J, Peng TI, Jones DP and Wang X: Prevention of apoptosis by Bcl-2: Release of cytochrome c from mitochondria blocked. Science 275: 1129-1132, 1997.

22. Gottschalk AR, Boise LH, Thompson CB and Quintáns J: Identification of immunosuppressant-induced apoptosis in a murine B-cell line and its prevention by bcl-x but not bcl-2. Proc Natl Acad Sci USA 91: 7350-7354, 1994.

23. Minn AJ, Rudin CM, Boise LH and Thompson CB: Expression of bcl-xL can confer a multidrug resistance phenotype. Blood 86: 1903-1910, 1995.

24. Kamesaki S, Kamesaki H, Jorgensen TJ, Tanizawa A, Pommier Y and Cossman J: Bcl-2 protein inhibits etoposide-induced apoptosis through its effects on events subsequent to topoisomerase II-induced DNA strand breaks and their repair. Cancer Res 53: 4251-4256, 1993 
25. Walton MI, Whysong D, O'Connor PM, Hockenbery D, Korsmeyer SJ and Kohn KW: Constitutive expression of human Bcl-2 modulates nitrogen mustard and camptothecin induced apoptosis. Cancer Res 53: 1853-1861, 1993.

26. Josefsson EC, James C, Henley KJ, Debrincat MA, Rogers KL, Dowling MR, White MJ, Kruse EA, Lane RM, Ellis S, et al: Megakaryocytes possess a functional intrinsic apoptosis pathway that must be restrained to survive and produce platelets. J Exp Med 208: 2017-2031, 2011.

27. Kaluzhny Y, Yu G, Sun S, Toselli PA, Nieswandt B, Jackson CW and Ravid K: Bcl-xL overexpression in megakaryocytes leads to impaired platelet fragmentation. Blood 100: 1670-1678, 2002.

28. Delbridge AR, Aubrey BJ, Hyland C, Bernardini JP, Di Rago L, Garnier JM, Lessene G, Strasser A, Alexander WS and Grabow S: The BH3-only proteins BIM and PUMA are not critical for the reticulocyte apoptosis caused by loss of the pro-survival protein BCL-XL. Cell Death Dis 8: e2914, 2017.

29. Afreen S, Bohler S, Müller A, Demmerath EM, Weiss JM, Jutzi JS, Schachtrup K, Kunze M and Erlacher M: BCL-XL expression is essential for human erythropoiesis and engraftment of hematopoietic stem cells. Cell Death Dis 11: 8, 2020.

30. Hafid-Medheb K, Augery-Bourget Y, Minatchy MN, Hanania N and Robert-Lézénès $\mathrm{J}$ : Bcl-XL is required for heme synthesis during the chemical induction of erythroid differentiation of murine erythroleukemia cells independently of its antiapoptotic function. Blood 101: 2575-2583, 2003.

31. Mason KD, Carpinelli MR, Fletcher JI, Collinge JE, Hilton AA, Ellis S, Kelly PN, Ekert PG, Metcalf D, Roberts AW, et al: Programmed anuclear cell death delimits platelet life span. Cell 128: 1173-1186, 2007.

32. Dolznig H, Habermann B, Stangl K, Deiner EM, Moriggl R, Beug $\mathrm{H}$ and Müllner EW: Apoptosis protection by the Epo target $\mathrm{Bcl}-\mathrm{X}(\mathrm{L})$ allows factor-independent differentiation of primary erythroblasts. Curr Biol 12: 1076-1085, 2002.

33. Garçon L, Rivat C, James C, Lacout C, Camara-Clayette V, Ugo V, Lecluse Y, Bennaceur-Griscelli A and Vainchenker W: Constitutive activation of STAT5 and Bcl-xL overexpression can induce endogenous erythroid colony formation in human primary cells. Blood 108: 1551-154, 2006.

34. Harb JG, Chyla BI and Huettner CS: Loss of Bcl-x in Ph+ B-ALL increases cellular proliferation and does not inhibit leukemogenesis. Blood 111: 3760-3769, 2008.

35. Sato T, Hanada M, Bodrug S, Irie S, Iwama N, Boise LH, Thompson CB, Golemis E, Fong L, Wang HG, et al: Interactions among members of the Bcl-2 protein family analyzed with a yeast two-hybrid system. Proc Natl Acad Sci USA 91: 9238-9242, 1994.

36. Minn AJ, Boise LH and Thompson CB: Bcl-x(S) anatagonizes the protective effects of Bcl-x(L). J Biol Chem 271: 6306-6312, 1996.

37. Ohta K, Iwai K, Kasahara Y, Taniguchi N, Krajewski S, Reed JC and Miyawaki T: Immunoblot analysis of cellular expression of Bcl-2 family proteins, Bcl-2, Bax, Bcl-X and Mcl-1, in human peripheral blood and lymphoid tissues. Int Immunol 7: 1817-1825, 1995.

38. Krajewski S, Krajewska M, Shabaik A, Wang HG, Irie S, Fong L and Reed JC: Immunohistochemical analysis of in vivo patterns of Bcl-X expression. Cancer Res 54: 5501-5507, 1994.

39. Liles WC and Klebanoff SJ: Regulation of apoptosis in neutrophils-Fas track to death. J Immunol 155: 3289-3291, 1995.

40. Sanz C, Benito A, Silva M, Albella B, Richard C, Segovia JC, Insunza A, Bueren JA and Fernández-Luna JL: The expression of $\mathrm{Bcl}-\mathrm{x}$ is downregulated during differentiation of human hematopoietic progenitor cells along the granulocyte but not the monocyte/macrophage lineage. Blood 89: 3199-3204, 1997.

41. Zhang L, Zhao H, Sun A, Lu S, Liu B, Tang F, Feng Y, Zhao L, Yang R and Han ZC: Early down-regulation of $\mathrm{Bcl}-\mathrm{xL}$ expression during megakaryocytic differentiation of thrombopoietin-induced CD34+ bone marrow cells in essential thrombocythemia. Haematologica 89: 1199-1206. 2004

42. Gregoli PA and Bondurant MC: The roles of Bcl-X(L) and apopain in the control of erythropoiesis by erythropoietin. Blood 90: 630-640, 1997

43. Moulding DA, Quayle JA, Hart CA and Edwards SW: Mcl-1 expression in human neutrophils: Regulation by cytokines and correlation with cell survival. Blood 92: 2495-2502, 1998.

44. Park JR, Bernstein ID and Hockenbery DM: Primitive human hematopoietic precursors express Bcl-x but not Bcl-2. Blood 86: 868-876, 1995.

45. Andreeff M, Jiang S, Zhang X, Konopleva M, Estrov Z, Snell VE, Xie Z, Okcu MF, Sanchez-Williams G, Dong J, et al: Expression of Bcl-2-related genes in normal and AML progenitors: Changes induced by chemotherapy and retinoic acid. Leukemia 13: 1881-1892, 1999.
46. Kaufmann SH, Karp JE, Svingen PA, Krajewski S, Burke PJ, Gore SD and Reed JC: Elevated expression of the apoptotic regulator Mcl-1 at the time of leukemic relapse. Blood 91: 991-1000, 1998.

47. Lotem J and Sachs L: Regulation of bcl-2, bcl-XL and bax in the control of apoptosis by hematopoietic cytokines and dexamethasone. Cell Growth Differ 6: 647-653, 1995.

48. Campos L, Sabido O, Viallet A, Vasselon C and Guyotat D: Expression of apoptosis-controlling proteins in acute leukemia cells. Leuk Lymphoma 33: 499-509, 1999.

49. Tsushima H, Urata Y, Miyazaki Y, Fuchigami K, Kuriyama K, Kondo $\mathrm{T}$ and Tomonaga $\mathrm{M}$ : Human erythropoietin receptor increases GATA-2 and Bcl-xL by a protein kinase C-dependent pathway in human erythropoietin-dependent cell line AS-E2. Cell Growth Differ 8: 1317-1328, 1997.

50. Findley HW, Gu L, Yeager AM and Zhou M: Expression and regulation of $\mathrm{Bcl}-2, \mathrm{Bcl}-\mathrm{xl}$, and $\mathrm{Bax}$ correlate with p53 status and sensitivity to apoptosis in childhood acute lymphoblastic leukemia. Blood 89: 2986-2993, 1997.

51. Bogenberger JM, Kornblau SM, Pierceall WE, Lena R, Chow D, Shi CX, Mantei J, Ahmann G, Gonzales IM, Choudhary A, et al: BCL-2 family proteins as 5-Azacytidine-sensitizing targets and determinants of response in myeloid malignancies. Leukemia 28: 1657-1665, 2014.

52. Gottardi D, Alfarano A, De Leo AM, Stacchini A, Aragno M, Rigo A, Veneri D, Zanotti R, Pizzolo G and Caligaris-Cappio F: In leukaemic CD5+ B cells the expression of BCL-2 gene family is shifted toward protection from apoptosis. Br J Haematol 94: 612-618, 1996.

53. Brousset P, Benharroch D, Krajewski S, Laurent G, Meggetto F, Rigal-Huguet F, Gopas J, Prinsloo I, Pris J, Delsol G, et al: Frequent expression of the cell death-inducing gene Bax in Reed-Sternberg cells of Hodgkin's disease. Blood 87: 2470-2475, 1996.

54. Wojtuszkiewicz A, Schuurhuis GJ, Kessler FL, Piersma SR, Knol JC, Pham TV, Jansen G, Musters RJ, van Meerloo J, Assaraf YG, et al: Exosomes secreted by apoptosis-resistant acute myeloid leukemia (AML) blasts harbor regulatory network proteins potentially involved in antagonism of apoptosis. Mol Cell Proteomics 15: 1281-1298, 2016.

55. Datta R, Manome Y, Taneja N, Boise LH, Weichselbaum R, Thompson CB, Slapak CA and Kufe D: Overexpression of Bcl-XL by cytotoxic drug exposure confers resistance to ionizing radiation-induced internucleosomal DNA fragmentation. Cell Growth Differ 6: 363-370, 1995.

56. Ibrado AM, Huang Y, Fang G and Bhalla K. Bcl-xL overexpression inhibits taxol-induced Yama protease activity and apoptosis. Cell Growth Differ 7: 1087-1094, 1996.

57. Ibrado AM, Huang Y, Fang G, Liu Land Bhalla K: Overexpression of Bcl-2 or Bcl-xL inhibits Ara-C-induced CPP32/Yama protease activity and apoptosis of human acute myelogenous leukemia HL-60 cells. Cancer Res 56: 4743-4748, 1996.

58. Xie C, Edwards H, Caldwell JT, Wang G, Taub JW and Ge Y: Obatoclax potentiates the cytotoxic effect of cytarabine on acute myeloid leukemia cells by enhancing DNA damage. Mol Oncol 9: 409-421, 2015.

59. Huang Y, Ibrado AM, Reed JC, Bullock G, Ray S, Tang C and Bhalla K: Co-expression of several molecular mechanisms of multidrug resistance and their significance for paclitaxel cytotoxicity in human AML HL-60 cells. Leukemia 11: 253-257, 1997.

60. Salomons GS, Smets LA, Verwijs-Janssen M, Hart AA, Haarman EG, Kaspers GJ, Wering EV, Der Does-Van Den Berg AV and Kamps WA: Bcl-2 family members in childhood acute lymphoblastic leukemia: Relationships with features at presentation, in vitro and in vivo drug response and long-term clinical outcome. Leukemia 13: 1574-1580, 1999.

61. Dole MG, Clarke MF, Holman P, Benedict M, Lu J, Jasty R, Eipers P, Thompson CB, Rode C, Bloch C, et al: Bcl-xS enhances adenoviral vector-induced apoptosis in neuroblastoma cells. Cancer Res 56: 5734-5740, 1996.

62. Sumantran VN, Ealovega MW, Nuñez G, Clarke MF and Wicha MS: Overexpression of Bcl-XS sensitizes MCF-7 cells to chemotherapy-induced apoptosis. Cancer Res 55: 2507-2510, 1995.

63. Deng G, Lane C, Kornblau S, Goodacre A, Snell V, Andreeff M and Deisseroth AB: Ratio of bcl-xshort to bcl-xlong is different in good- and poor-prognosis subsets of acute myeloid leukemia. Mol Med 4: 158-164, 1998

64. Souers AJ, Leverson JD, Boghaert ER, Ackler SL, Catron ND, Chen J, Dayton BD, Ding H, Enschede SH, Fairbrother WJ, et al: ABT-199, a potent and selective BCL-2 inhibitor, achieves antitumor activity while sparing platelets. Nat Med 19: 202-208, 2013. 
65. Oltersdorf T, Elmore SW, Shoemaker AR, Armstrong RC, Augeri DJ, Belli BA, Bruncko M, Deckwerth TL, Dinges J, Hajduk PJ, et al: An inhibitor of Bcl-2 family proteins induces regression of solid tumours. Nature 435: 677-681, 2005.

66. Tse C, Shoemaker AR, Adickes J, Anderson MG, Chen J, Jin S, Johnson EF, Marsh KC, Mitten MJ, Nimmer P, et al: ABT-263: A potent and orally bioavailable Bcl-2 family inhibitor. Cancer Res 68: 3421-3428, 2008

67. Jilg S, Reidel V, Müller-Thomas C, König J, Schauwecker J, Höckendorf U, Huberle C, Gorka O, Schmidt B, Burgkart R, et al: Blockade of BCL-2 proteins efficiently induces apoptosis in progenitor cells of high-risk myelodysplastic syndromes patients. Leukemia 30: 112-123, 2016.

68. Lessene G, Czabotar PE, Sleebs BE, Zobel K, Lowes KN, Adams JM, Baell JB, Colman PM, Deshayes K, Fairbrother WJ, et al: Structure-guided design of a selective BCL-X(L) inhibitor. Nat Chem Biol 9: 390-397, 2013.

69. Sleebs BE, Kersten WJ, Kulasegaram S, Nikolakopoulos G, Hatzis E, Moss RM, Parisot JP, Yang H, Czabotar PE, Fairlie WD, et al: Discovery of potent and selective benzothiazole hydrazone inhibitors of Bcl-XL. J Med Chem 56: 5514-5540, 2013.

70. Konopleva M, Pollyea DA, Potluri J, Chyla B, Hogdal L, Busman T, McKeegan E, Salem AH, Zhu M, Ricker JL, et al: Efficacy and biological correlates of response in a phase II study of venetoclax monotherapy in patients with acute myelogenous leukemia. Cancer Discov 6: 1106-1117, 2016.

71. Roberts AW, Davids MS, Pagel JM, Kahl BS, Puvvada SD, Gerecitano JF, Kipps TJ, Anderson MA, Brown JR, Gressick L, et al: Targeting BCL2 with venetoclax in relapsed chronic lymphocytic leukemia. N Engl J Med 374: 311-322, 2016.

72. Stilgenbauer S, Eichhorst B, Schetelig J, Coutre S, Seymour JF, Munir T, Puvvada SD, Wendtner CM, Roberts AW, Jurczak W, et al: Venetoclax in relapsed or refractory chronic lymphocytic leukaemia with $17 \mathrm{p}$ deletion: A multicentre, open-label, phase 2 study. Lancet Oncol 17: 768-778, 2016.

73. Lin KH, Winter PS, Xie A, Roth C, Martz CA, Stein EM, Anderson GR, Tingley JP and Wood KC: Targeting MCL-1/BCL-XL forestalls the acquisition of resistance to ABT-199 in acute myeloid leukemia. Sci Rep 6: 27696, 2016.

74. Punnoose EA, Leverson JD, Peale F, Boghaert ER, Belmont LD Tan N, Young A, Mitten M, Ingalla E, Darbonne WC, et al: Expression profile of BCL-2, BCL-XL, and MCL-1 predicts pharmacological response to the BCL-2 selective antagonist venetoclax in multiple myeloma models. Mol Cancer Ther 15: 1132-1144, 2016.

75. Schoenwaelder SM, Jarman KE, Gardiner EE, Hua M, Qiao J, White MJ, Josefsson EC, Alwis I, Ono A, Willcox A, et al: Bcl-xL-inhibitory $\mathrm{BH} 3$ mimetics can induce a transient thrombocytopathy that undermines the hemostatic function of platelets. Blood 118: 1663-1674, 2011.
76. Kile BT: The role of apoptosis in megakaryocytes and platelets Br J Haematol 165: 217-226, 2014.

77. Roberts AW, Seymour JF, Brown JR, Wierda WG, Kipps TJ, Khaw SL, Carney DA, He SZ, Huang DC, Xiong H, et al: Substantial susceptibility of chronic lymphocytic leukemia to BCL2 inhibition: Results of a phase I study of navitoclax in patients with relapsed or refractory disease. J Clin Oncol 30: 488-496, 2012

78. Khan S, Zhang X, Lv D, Zhang Q, He Y, Zhang P, Liu X, Thummuri D, Yuan Y, Wiegand JS, et al: A selective BCL-X, PROTAC degrader achieves safe and potent antitumor activity. Nat Med 25: 1938-1947, 2019.

79. He Y, Zhang X, Chang J, Kim HN, Zhang P, Wang Y, Khan S, Liu X, Zhang X, Lv D, et al: Using proteolysis-targeting chimera technology to reduce navitoclax platelet toxicity and improve its senolytic activity. Nat Commun 11: 1996, 2020.

80. Tao ZF, Hasvold L, Wang L, Wang X, Petros AM, Park CH, Boghaert ER, Catron ND, Chen J, Colman PM, Czabotar PE, et al: Discovery of a potent and selective BCL-XL inhibitor with in vivo activity. ACS Med Chem Lett 5: 1088-1093, 2014.

81. Wang Q,WanJ,Zhang W and HaoS:MCL-1 or BCL-xL-dependent resistance to the BCL-2 antagonist (ABT-199) can be overcome by specific inhibitor as single agents and in combination with ABT-199 in acute myeloid leukemia cells. Leuk Lymphoma 60: 2170-2180, 2019.

82. Zhu Y,Doornebal EJ, Pirtskhalava T, Giorgadze N, Wentworth M, Fuhrmann-Stroissnigg H, Niedernhofer LJ, Robbins PD, Tchkonia T and Kirkland JL: New agents that target senescent cells: The flavone, fisetin, and the BCL- $\mathrm{X}_{\mathrm{L}}$ inhibitors, A1331852 and A1155463. Aging (Albany NY) 9: 955-963, 2017.

83. Wang L, Doherty GA, Judd AS, Tao ZF, Hansen TM, Frey RR, Song X, Bruncko M, Kunzer AR, Wang X, et al: Discovery of A-1331852, a First-in-Class, potent, and orally-bioavailable BCL-X $_{\mathrm{L}}$ inhibitor. ACS Med Chem Lett 11: 1829-1836, 2020.

84. Kirkland JL and Tchkonia T: Cellular senescence: A translational perspective. EBioMedicine 21: 21-28, 2017.

85. Perri M, Yap JL, Yu J, Cione E, Fletcher S and Kane MA: BCL-xL/MCL-1 inhibition and RAR $\gamma$ antagonism work cooperatively in human HL60 leukemia cells. Exp Cell Res 327: 183-191, 2014.

This work is licensed under a Creative Commons Attribution-NonCommercial-NoDerivatives 4.0 International (CC BY-NC-ND 4.0) License. 